\title{
Antimicrobial, Antioxidant and Cytotoxic Activity of Marine Streptomyces parvulus VITJS11 Crude Extract
}

\author{
S. Jemimah Naine, C. Subathra Devi", V. Mohanasrinivasan and Vaishnavi. B. \\ School of Biosciences and Technology; VIT University; Vellore, Tamil Nadu - India
}

\begin{abstract}
The main aim of the study was to evaluate the bioactive properties of ethyl acetate crude extract of Streptomyces parvulus VITJS11 with a view to assess their therapeutic potential. The biological activity of ethyl acetate extract was tested against fungal and bacterial pathogens. The free radical scavenging potential of the crude extract was determined by DPPH assay. The chemo preventive properties of S. parvulus VITJS11 ethyl acetate extract was examined by MTT assay on HepG2 cells. The morphological, physiological and the biochemical properties of the strain S. parvulus VITJS11 was confirmed by conventional methods. Genotypic characterization was done using $16 S$ $r$-DNA partial gene amplification and sequencing. The authenticity of the crude chemical constitutes were determined by the GC-MS. The ethyl acetate extract of VITJS11 showed maximum antifungal activity against three Aspergillus species and prominent antibacterial activity against two Gram positive and Gram negative bacteria at $20 \mathrm{mg} / \mathrm{mL}$. The antioxidant potential of the crude extract exhibited strong reducing power activity at $5 \mathrm{mg} / \mathrm{mL}$ with $85 \%$ inhibition and the cytotoxic effect was found with $\mathrm{IC}_{50}$ of $500 \mu \mathrm{g} / \mathrm{mL}$ on HepG 2 cell lines. The GC-MS analysis and the chromatogram patterns revealed 16 peaks, indicating the presence of bioactive constituents, which included several important organic compounds, namely 9-(2',2'-dimethylpropanoilhydrazono)-3,6-dichloro-2,7-Bis-[2(diethylamino)-ethoxy]fluorine (23.1) Dotriacontylpentafluoropropionate,(25.0) Octadecanoic acid, (20.0); Trans2-methyl-4-n-butylthiane, S, S-dioxide.(19.0). The results showed the benefit of ethyl acetate extract from S. parvulus VITJS11 in treating microbial infections and indicated their broad spectrum of activity with beneficial virtues for therapeutic use.
\end{abstract}

Key words: Marine actinomycetes, Streptomyces parvulus VITJS11, antimicrobial activity, antioxidants, cytotoxicity, bioactive compounds

\section{INTRODUCTION}

The development of drug resistance by the pathogens is due to the concurrent usage of existing antibiotics. The search for new, safer, broad-spectrum antibiotic with greater potency has been progressing slowly (Gupte et al. 2002). Hence, to combat these drug resistant pathogens, new antibiotics are in need and should be developed. There is no satisfactory drug as of now to control the occurrence of cancer and it is known to be the leading cause of death worldwide
(Taylor et al. 2007). The limited availability to control cancer drug resistance along with the emergence of new pathogens has led the expansion of the search for novel drug candidates. In fact, the list of novel microorganisms, especially actinobacteria and their products found in microbiologically unexplored ecosystems. In the course of screening for new antibiotics, several studies are oriented towards the isolation of new bacterial species from different soils and ecosystems (Mellouli et al. 2003). Actinomycetes are ubiquitous in the marine environment and in,

*Author for correspondence: csubathradevi@vit.ac.in 
actinomycetes, Streptomyces species are one of the largest sources of bioactive natural products and they are taxonomically diverse and biologically active. The potential contribution of marine Streptomyces in the discovery of new bioactive molecules is increasingly challenging and the study of marine Streptomyces and their potential role in the production of metabolites is becoming an interesting new topic for research. Several investigations have shown an increasing number of biologically active and structurally unique compounds from it (Hardt et al. 2000; Marsgy et al. 2001). Indian coastal region is an ideal location for harvesting many valuable species producing bioactive compounds with numerous complex and novel chemical entities. Recently, much attention has been directed toward biologically active compounds from natural products as they exhibit fewer side effects in comparison to orthodox medical drugs. However, the potential beneficial effects of these natural compounds need to be confirmed in large, rigorous trials. These structures can be chemically modified and improved through knowledge of the structure-activity relationship, mechanism of action, drug metabolism, molecular modelling and combinatorial chemistry studies. The discovery of new active metabolites must be followed by adequate biological testing (Jemimah et al. 2014). Hence, the aim of this study was to investigate the bioactive potential of $S$. parvulus VITJS11 crude extracts from marine environment of Bay of Bengal, South coast of India for its antifungal, antibacterial, antioxidant and cytotoxic potential.

\section{MATERIALS AND METHODS}

\section{Sample collection and isolation}

Marine soil samples were collected from the south East coast of India, Ramanathapuram- Sethu Karai (Lat.9 $9^{\circ} 50^{\prime \prime} \mathrm{N}$ and $78^{\circ} 10^{\prime} \mathrm{E}$ ) at the depth of $10-100$ $\mathrm{cm}$ at littoral zone and the collected samples were stored at $4^{\circ} \mathrm{C}$. The isolation was performed on selective media such as actinomycetes isolation agar (AIA), Kuster's agars, Bennett agar, Starch casein agar along with $25 \%$ marine water and $25 \%$ marine soil extract for effective isolation (Balagurunathan et al. 2001). All the plates were incubated at $30^{\circ} \mathrm{C}$ for $1-2$ weeks. Emerging isolates were sub cultured on ISP2 agar and stored under refrigeration. The morphological and cultural characteristics were determined on various ISP medium (Newman et al. 2003; Ravikumar et al. 2008).

\section{Cross streak method}

The $S$. parvulus VITJS11 was cross streaked on the modified nutrient glucose agar plates near the periphery against wide range of Gram-positive and Gram-negative bacteria at right angle and incubated for three days (Alexander et al. 1977; Brock et al. 1994).The zone of inhibition was measured after two days of incubation.

\section{Scanning electron microscopy}

Streptomyces parvulus VITJS11 was grown on starch casein agar at $27^{\circ} \mathrm{C}$ for seven days. The spore chain morphology and spore surface ornamentation was evaluated by scanning electron microscopy analysis.

\section{Fermentation and extraction of antibacterial compound}

The inoculum of $S$. parvulus VITJS11 was prepared on starch casein broth at a seed concentration of $100 \mathrm{~mL}$ in a $250 \mathrm{~mL}$ Erlenmeyer flask ( $\mathrm{pH}$ 7.2) incubating at room temperature for seven days. For the isolation of bioactive compounds, extraction process was carried out successively with using ethyl acetate solvent with increasing polarity. The crude extract powder was weighed and studied for its bioactivity (Remya et al. 2007).

\section{Test organisms}

The pathogens, including Aspergillus niger MTCC No:872; A. fumigatus MTCC No:8877; $A$. flavus MTCC No:8790; Pseudomonas aeruginosa (MTCC No: 4676), Staphylococcus aureus (MTCC No: 7405), Salmonella typhi (MTCC No: 1167), Escherichia coli (MTCC No: 1588), were obtained from the Microbial culture collection, IMTECH, Chandigarh, INDIA.

\section{Determination of antifungal activity}

The antifungal activity was assessed by agar-well diffusion assay. The culture medium of sabouraud dextrose broth was inoculated with the fungal strains and was adjusted to $1 \times 10^{8} \mathrm{CFU} / \mathrm{mL}$. Then $100 \mu \mathrm{L}$ of the inoculum was placed on the sabouraud dextrose agar and the wells were filled with $100 \mu \mathrm{L}$ of $20 \mathrm{mg} / \mathrm{mL}$ S. parvulus VITJS11 crude extract. The plates were incubated at $27^{\circ} \mathrm{C}$ for $72 \mathrm{~h}$. The antifungal activity was evaluated by measuring the zone of inhibition of fungal growth. 


\section{Agar-well diffusion assay}

The in vitro antibacterial activity of all the solvent extracts of $S$. parvulus VITJS11 was determined by agar- well diffusion method (Pandey et al. 2004). Log phase bacterial cultures of $10^{8} \mathrm{CFU} / \mathrm{mL}$ were used. One hundred microlitre of various concentrations ranging $1.0-20 \mathrm{mg} / \mathrm{mL}$ of crude extract of $S$. parvulus VITJS11 were tested. Diameter of the zone was measured and expressed in $\mathrm{mm}$.

\section{Free radical Scavenging Activity}

The antioxidant activity was determined by DPPH scavenging assay (Khalaf et al. 2008). Various concentration $(0.1,0.5,1.0,3.0$ and $5.0 \mathrm{mg} / \mathrm{mL})$ of $S$. parvulus VITJS11 crude extract was taken in separate tubes. Ascorbic acid was used as reference compound $(0.1,0.5,1.0,3.0$ and 5.0 $\mathrm{mg} / \mathrm{mL}$ ). A freshly prepared solution of $0.002 \%$ DPPH (2, 2, Diphenyl-2-Picryl hydrazyl) in methanol was added to each tube containing different concentrations of extracts $(2.0 \mathrm{~mL})$. The samples were incubated in dark at $37{ }^{\circ} \mathrm{C}$ for 20 min and read at $515 \mathrm{~nm}$. The data were expressed as the percent decrease in the absorbance compared to the control. The percentage inhibition of radical scavenging activity was calculated.

\section{Maintenance of cell cultures}

The HepG2 cells were obtained from NCSS, Pune and cultured in RPMI-1640 medium on $10 \mathrm{~cm}$ tissue culture dishes (Greiner Bio-one ${ }^{\mathrm{TM}}$, Germany) supplemented with $10 \%$ heat inactivated fetal bovine serum. Cells were incubated in humidified incubator with $5 \% \mathrm{CO}_{2}$ at $37^{\circ} \mathrm{C}$, and sub cultured when confluence was reached up to $80 \%$ (Freshney et al. 1982).

\section{Cell viability assay}

The 3-(4, 5-dimethylthiazol-2-yl)-2-5-diphenyl tetrazolium bromide) MTT assay, was used to assess the viability of the cells (Mosmann et al. 1983). The HepG 2 cells $\left(5 \times 10^{3}\right)$ were seeded per well into 96-well plates containing $100 \mu \mathrm{L}$ DMEM medium with $10 \% \mathrm{FBS}$ incubated at $37^{\circ} \mathrm{C}$ for $24 \mathrm{~h}$, Then, the cells were treated with $100 \mu \mathrm{L}$ of the $S$. parvulus VITJS11 crude extract in triplicates with different concentrations ranging from 50 to $1000 \mu \mathrm{g} / \mathrm{mL}$. Doxorubicin $(5 \mu \mathrm{g} / \mathrm{mL})$ was used as internal positive control and $100 \mu \mathrm{L}$ of DMEM was used as negative control; wells without any cells were considered as blank. After incubating in humidified incubator with $5 \% \mathrm{CO}_{2}$ at $37^{\circ} \mathrm{C}$ for $48 \mathrm{~h}, 20 \mu \mathrm{L}$ of $5 \mathrm{mg} / \mathrm{mL}$ MTT diluted in PBS were added to each well and incubated for $4 \mathrm{~h}$. One hundred microlitre of $10 \%$ SDS in, $0.01 \mathrm{M} \mathrm{HCl}$ solution was added to each well to dissolve the formazan crystals formed. The plates were covered with aluminium foil and kept in an incubator for $12 \mathrm{~h}$ for dissolution of the formed formazan crystals. Amount of formazan was determined measuring the absorbance at $560 \mathrm{~nm}$ using a micro plate reader.

\section{Molecular Characterization}

Total genomic DNA was isolated using the phenol chloroform method (Nathan et al. 2004). PCR amplification of $16 \mathrm{~S}$ r-DNA was carried out using the primers $\mathrm{FC} 27$ (5', to 3'AGAGTTTGATCCTGGCTCAG) and RC 1492 (5',to3' TACGGCTACCTT GTTACGACTT) (Rainey et al. 1996). The PCR product was detected by agarose gel electrophoresis. Sequencing was performed using big dye terminator cycle sequencing kit (Applied Bio Systems, USA). The sequence was subjected to homology search using BLAST programme of the National Centre for Biotechnology Information (NCBI) and the sequence data was submitted to the GenBank database under the accession number (KC961640).

\section{Phylogenetic analysis}

The acquired sequences was used for a gene homology search, with the 16S r-DNA sequences available in the public databases from BLAST and identified to the generic level (Altschul et al. 1997; Benson et al. 1999). Using the CLUSTAL$\mathrm{X}$ Multiple Sequence Alignment Program (Strasburg, France), the 16S r-DNA sequences of the strains were aligned with sequences of related organisms obtained from GenBank and a phylogenetic tree was constructed via the neighbor-joining method using the EvolView program (Huangkai et al. 2012). To validate the reproducibility of the branching pattern, a bootstrap analysis was performed.

\section{GC-MS analysis}

Streptomyces parvulus VITJS11 crude extract was subjected to GC-MS. The analysis was performed using GC SHIMADZU QP2010 system. NIST08 and WILEY8 database were used for the identification of the separated peaks and the relative percentage of each component was 
calculated by comparing its average peak area to the total areas. (Jemimah et al. 2013)

\section{RESULTS AND DISCUSSION}

Recently, numerous pathogens have developed resistance due to the indiscriminate use of commercial antimicrobial drugs. Hence, there is an urge to search the novel drugs against such pathogens. It has been envisaged that marine environment are extreme source to provide exciting new bioactive compounds. In the present study, an attempt was made to identify the bioactive potential of $S$. parvulus VITJS11. The morphology, biochemical and taxonomical characterization of $S$. parvulus VITJS11 represented the features of Streptomycetaceae family belonging to genera Streptomyces (Table 1).

Table 1 - Morphological properties, biochemical, cultural and process parameters of Streptomyces parvulus VITJS11.

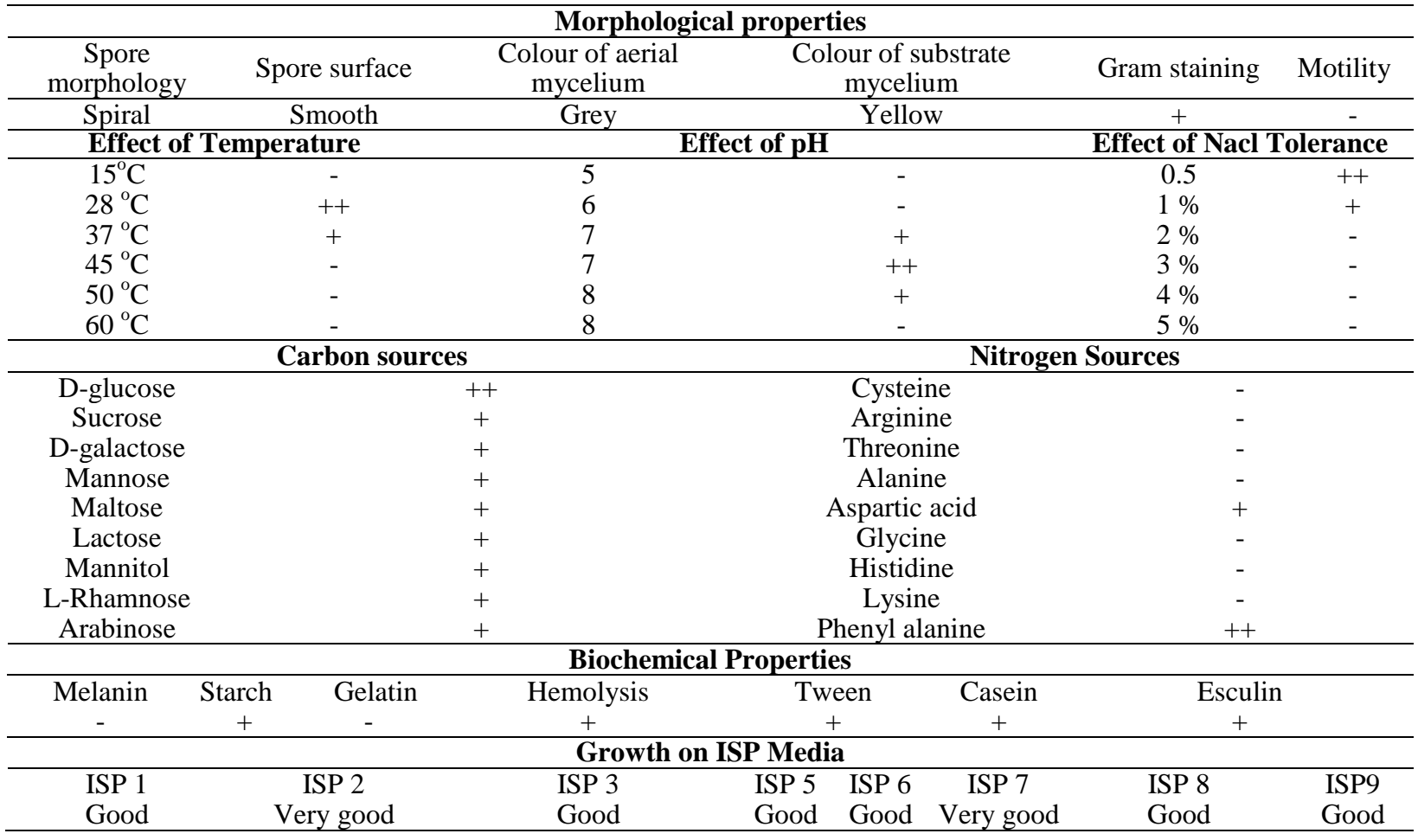

The strain was studied on the basis of its morphology and recognized by their presence of aerial hyphae with grey coloration on starch casein medium. The frequent production of spreading substrate mycelia was observed and the colonies were found darkened during sporulation with spirals. The colonies with powdery appearance had a characteristic feature with smooth surface. The ornamentation of spore surface of $S$. parvulus
VITJS11 was observed under light microscopy. Scanning electron microscopy (magnification, 6,000 ) showed aerial mycelium bearing spores with $0.7 \mu \mathrm{m}$ (Fig. 1).

The physiological characteristics of the S. parvulus VITJS11 was compared with Streptomyces species given in the key of Nonomura. The strain VITJS11 showed more similarity to the reference strain, $S$. parvulus (Table 2 ). 


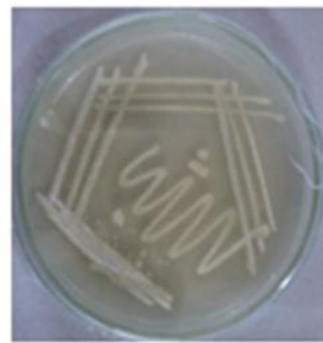

(A)

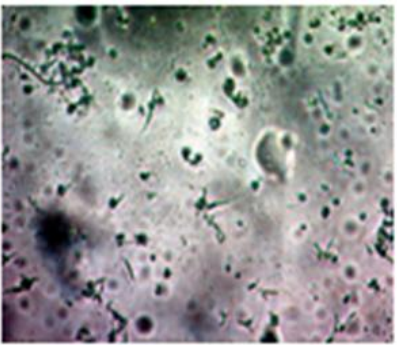

(B)

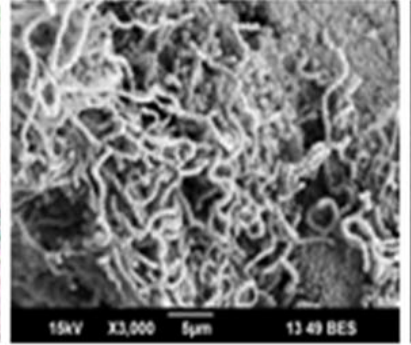

(C)

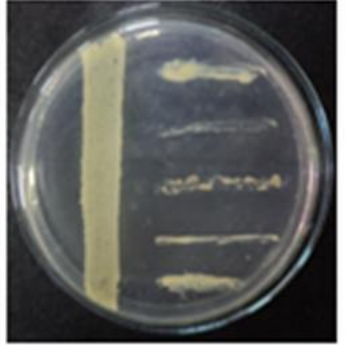

(D)

Figure 1 - Streptomyces parvulus VITJS11- (A) Pure culture plate of on starch casein agar; (B) Light microscopy at 40X; (C) Scanning electron microscopy; (D) Cross streak assay of the strain against the bacterial pathogens.

Table 2 - Comparison of morphological and biochemical characteristics of Streptomyces parvulus VITJS11 with reference strain.

\begin{tabular}{lcc}
\hline & $\begin{array}{c}\text { S. parvulus } \\
\text { VITJS11 }\end{array}$ & S. parvulus \\
\hline Colour of aerial mycelium & Grey & Grey \\
Melanoid pigment & - & - \\
Reverse side pigment & - & - \\
Soluble pigment & - & - \\
Spore chain morphology & Spiral & Spiral \\
Utilization of carbon & & \\
Sources & & \\
Arabinose & + & + \\
Xylose & + & + \\
Inositol & + & + \\
Mannitol & + & + \\
Fructose & + & + \\
Rhamnose & + & + \\
Sucrose & + & + \\
Raffinose & + & + \\
\hline
\end{tabular}

The antifungal activity of $S$. parvulus VITJS11 was examined against three pathogenic species of Aspergillus. The strongest inhibition of fungal growth was noticed against A.niger of $30 \mathrm{~mm}$ at $20 \mathrm{mg} / \mathrm{mL}$ concentration and A.fumigatus (25 $\mathrm{mm})$, A.flavus $(21 \mathrm{~mm})$. The results could be useful for the better understanding of the biocontrol mechanisms of the fungal strains, indicating that the strain VITJS11 probably producing a bioactive potential with antifungal component (Fig. 2). The strain S. parvulus VITJS11 subjected to primary screening for its activity against bacterial pathogens was confirmed by the cross streak method. The crude extract of the isolate further subjected to agar well diffusion method comparatively exhibited potent activity for all the clinical pathogens tested. The most active antibacterial crude fraction was obtained by the solvent mixture of ethyl acetate. The antibacterial effects of crude extract showed activity against the bacterial pathogens.

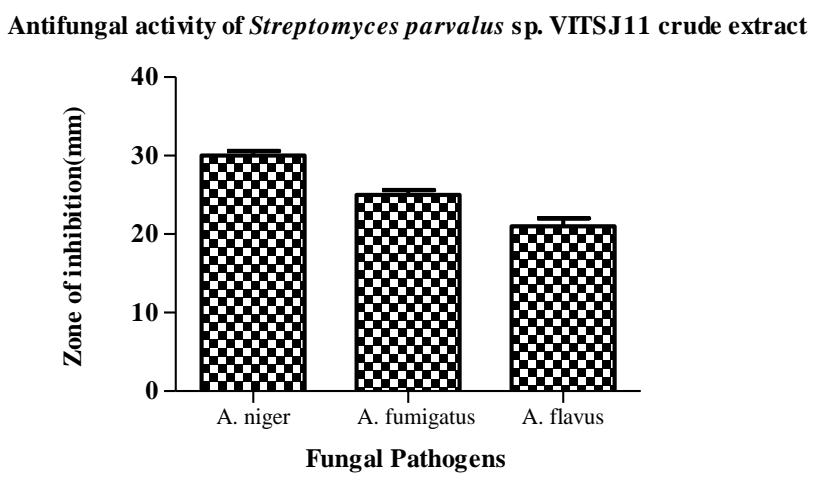

(A)

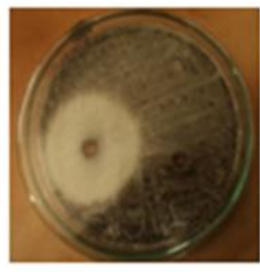

a

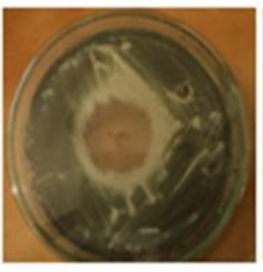

(B)

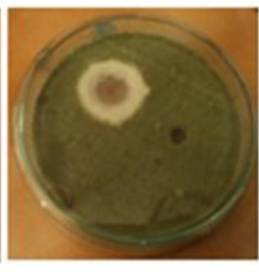

$c$
Figure 2 - (A) Graphical representation of antifungal activity of Streptomyces parvulus VITJS11 crude extract ; (B) Pictorial view showing the inhibition of fungal pathogens(a) Aspergillus niger $[30 \mathrm{~mm}]$ (b) Aspergillus fumigatus $[25 \mathrm{~mm}]$ (c) Aspergillus flavus [21 mm].

The maximum activity was found at $26 \mathrm{~mm}$, which was observed against $S$. typhi and $E$. coli, followed by $S$. aureus $24 \mathrm{~mm}$ and $P$. aeruginosa with 20 $\mathrm{mm}$ diameter of inhibition at the maximum concentration of $20 \mathrm{mg} / \mathrm{mL}$. The intensity of the inhibitory effects was comparable with the positive control (Fig. 3). The current results were 
also supported by the findings of similar study on Streptomyces strains, which were showing better antifungal activity observed against Aspergillus niger and strong antibacterial activity against Gram positive and Gram negative bacteria (Laidi et al. 2007; Oskay et al.2009). The studies on marine Streptomyces $s p$ exhibited good antimicrobial activity against clinical pathogens (Ponmurugan et al. 2008). The concurrent studies of Streptomyces sp PM-32 isolated from off-shore sediments collected at the Bay of Bengal coast was reported to have antimicrobial activity against a group of bacterial and fungal pathogens (Manivasagan et al. 2009). Studies on antibacterial activity from Streptomyces sp SLO-105 was found against Gram-positive bacteria ( $S$. aureus, methicillin-resistant $S$. aureus (MRSA), Micrococcus luteus) and antifungal activity against Aspergillus niger (Morakchi et al. 2009; Ko et al. 2010).

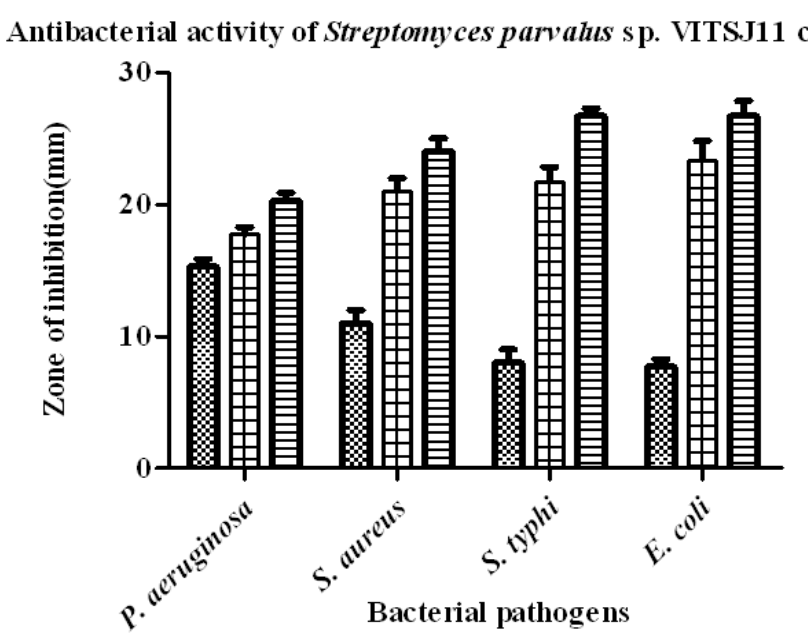

(A)

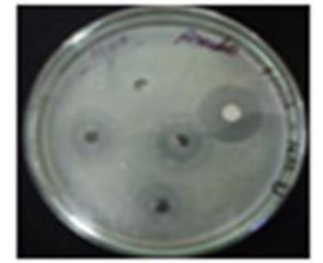

a

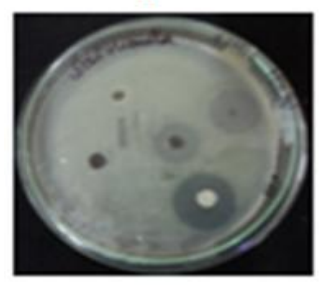

c

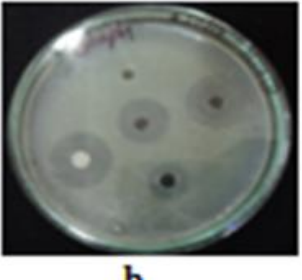

b

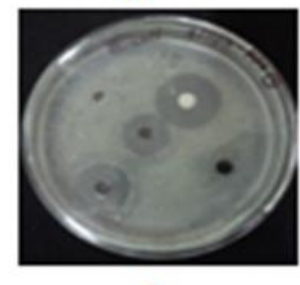

d

(B)

Figure 3 - (A) Graphical representation of antibacterial activity of Streptomyces parvulus VITJS11 crude extract; (B) Pictorial view showing the inhibition of bacterial pathogens at the maximum concentration $20 \mathrm{mg} / \mathrm{mL}$ (a) Pseudomonas aeruginosa [20 mm (b) Staphylococcus aureus $[24 \mathrm{~mm}]$ (c) Salmonella typhi $[26 \mathrm{~mm}]$ (d) Escherichia coli [26 $\mathrm{mm}]$.

The present study correlated with the existing report where the strain SRB25 was more similar to Streptomyces with antimicrobial property against multidrug resistance $S$. aureus (Sathish et al. 2012). The active compound of Streptomyces KUAP106 was effective against Gram-positive, Gram-negative and unicellular filamentous fungi (Usha et al. 2010). The Streptomyces sp. isolated from saline farm-lands showed both antibacterial and antifungal activity (Sajid et al. 2009). The antioxidant activity of the VITJS11 crude extract showed maximum activity with $85 \%$ inhibition at $5.0 \mathrm{mg} / \mathrm{mL}$ concentration and its activity remained highly significant with the reference used (Fig.4).
Antioxi dant potential of Streptonyces parvalus sp VITS.J1 1 crude extr act

$\otimes$ Crude extract

㹂 Ascorbic acid standard

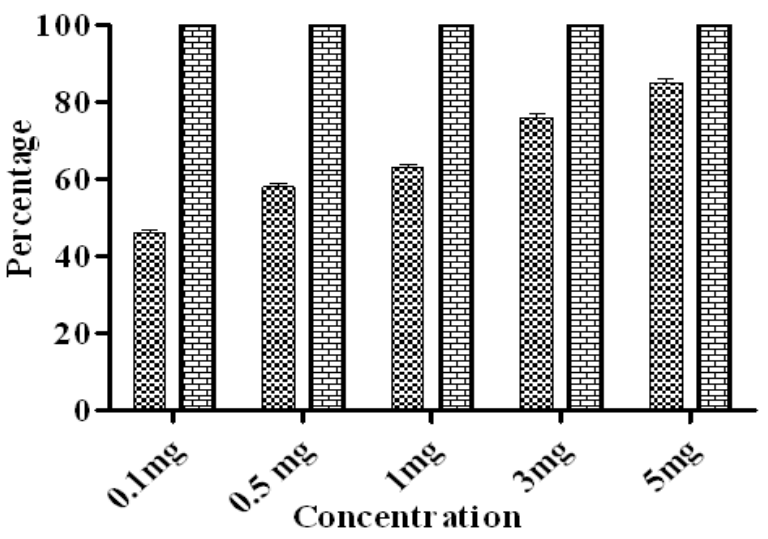

Figure 4 - Graphical representation of antioxidant property of Streptomyces parvulus VITJS 11 crude extract. 
Human hepatocellular liver carcinoma cell lines (HepG2) was used as a model system to examine chemo-preventive effect of $S$. parvulus VITJS11. The concentration of the extract varied from 50 to $1000 \mu \mathrm{g} / \mathrm{mL}$ The $\mathrm{IC}_{50}$ value was $500 \mu \mathrm{g} / \mathrm{mL}$ on HepG2 cells lines and exhibited substantial growth inhibition with $21 \%$ viability (Fig. 5). The HepG2 cell death resembled apoptosis, which was special evident with most notorious effect for strain VITJS11 crude extract. It was interesting to note that the strain VITJS11 crude extract resulted higher percentage of apoptotic cells. One possibility of the apoptotic phenomenon could be that the compounds in the extract interfering with mitosis would have lead to apoptosis within short period of time. Actinomycin D is the most significant member of actinomycins, which are a class of polypeptide antibiotics isolated from Streptomyces genus (Hollstein et al. 1974). Actinomycin D decreases Mcl-1 expression and acts synergistically with ABT-737 against small cell lung cancer cell lines (Aishan et al. 2010). Among the members of actinomycetes genus, Streptomyces sp is a dynamic producer of functional, bio-effective metabolites with broad pharmaceutical range having antimicrobial, antihelminthic, antitumor and antiviral agents (Ravikumar et al. 2008).

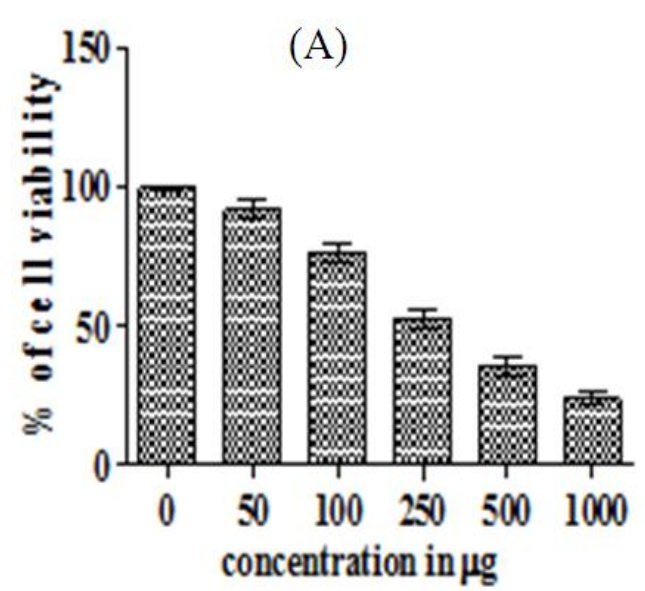

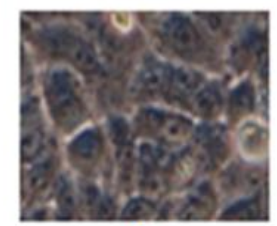

A

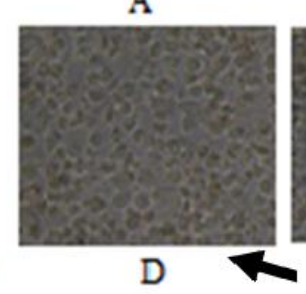

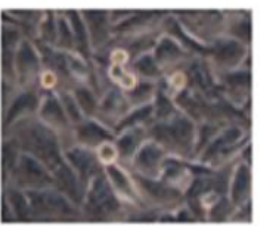

B

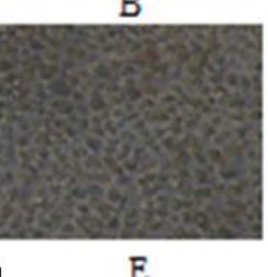

$\mathrm{E}$

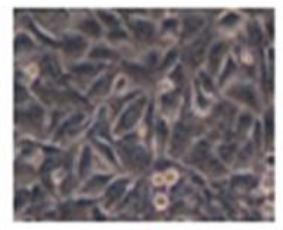

$\mathrm{C}$

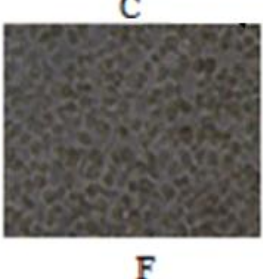

(B)

Figure 5 - (A) Percentage of cell viability shows the effective drug concentration toxic to HepG2 cell lines. (B) Morphological changes of HepG2 cell lines treated with crude extract of Streptomyces parvulus VITJS11. Cells were visualized under inverted light microscope Detachment of cells from substratum; cell shrinkage, nuclear condensation and fragmentation were evident in cells treated.

The phylogenetic analysis of $S$. parvulus VITJS11 was identified based on the nucleotide sequences of their 16S r-DNA genes, which showed similarity values of $98 \%$ to $16 \mathrm{~S}$ r-DNA genes of firmicutes in the NCBI database and the isolate revealed species level similarity to $S$. parvulus S10. Phylogenetic tree construction was conducted using neighbor joining algorithm with bootstrap values based on 1000 replications and the annotation, tree visualizing was performed using EVOLVIEW (a web application tool). The generated tree revealed that the isolate shared close affinity with Streptomyces species (Fig. 6).

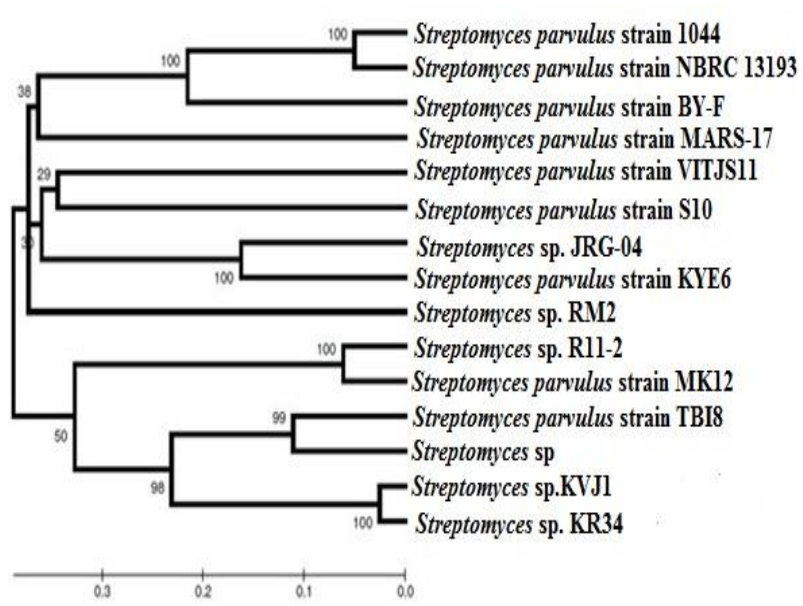

Figure 6 - Phylogenetic tree based on partial 16S rDNA sequences, showing the relationship with other species belong to the genus Streptomyces. 
The presence of volatile chemical constituents of ethyl acetate crude extract were analyzed by the GC-MS analysis and the chromatogram patterns revealed 16 peaks, indicating the presence of bioactive constituents, which included several important organic compounds namely 9-(2',2'dimethylpropanoilhydrazono)-3,6-dichloro-2,7BIS-[2-(diethylamino)-ethoxy]fluorine(23.1)

Dotriacontyl pentafluoropropionate (25.0) Octadecanoic acid (20.0); Trans-2-methyl-4-nbutylthiane, S, S-dioxide (19.0). Interpretation on mass spectrum of GC-MS was done using the database NIST08, WILEY8 (Fig. 7). In the present study, the partial characteristics of the active molecules indicated that bioactivity was likely to be due to the production of potential organic substances. The chemical fingerprints of the crude extract was identified and further manifested in differentiation from the related chemical profiles. Hence, the poor availability of drugs and the increasing number of treatment failures have motivated current searches for therapeutic alternatives which can work effectively as potential antimicrobial agents (Pina-Vaz et al. 2004). Thus, the new antimicrobial marine Streptomyces derivatives could be useful alternatives for the treatment of fungal and bacterial infections. The advantages of using these bioresources and their and its natural compounds may reduce the risk of side effects and lower the cost.

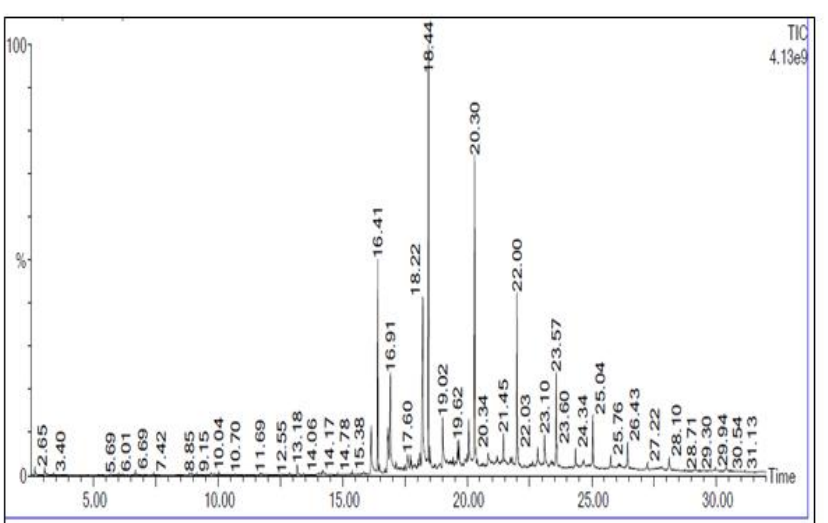

(A)

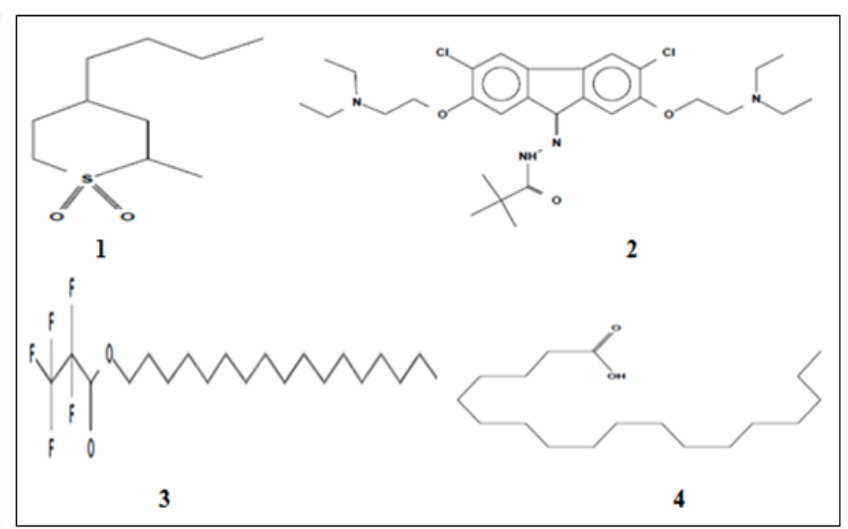

(B)

Figure 7 - Streptomyces parvulus VITJS11 crude extract (A) Chromatogram(B) GC-MS peaks of major volatile bioactive metabolites with molecular structure (1) 9-(2',2'Dimethylpropanoilhydrazono)-3,6-Dichloro-2,7-Bis-[2 Diethylamino) Ethoxy]Fluorene; (2)Dotriacontylpentafluoropropionate; (3) Octadecanoicacid; (4) Trans-2-Methyl-4-N Butyl Thiane, S, S-Dioxide.

\section{CONCLUSION}

Streptomyces parvulus VITJS11 showed various bioactive properties, which highlighted its importance as potential pharmacological agents. Hence, there could be probability of new bioactive compound in the crude extract, which might provide a basis for further development of novel compound from $S$. parvulus VITJS11.This also provided a new insight towards the development of good candidates for pharmaceutical and bioactive natural products.

\section{ACKNOWLEDGEMENT}

We are greatly indebted to Vellore Institute of Technology for the constant encouragement, help and support for extending necessary facilities.

\section{REFERENCES}

Aishan H, Xu, Geoffrey W Krystal. Actinomycin D Decreases Mcl-1 Expression and Acts Synergistically with ABT-737 against Small Cell Lung Cancer Cell Lines. Clin Cancer Res. 2010; 16:4392-43400. 
Alexander M. Introduction to soil microbiology. 2nd edn. John Wiley \& Sons, New York, 1977: 207.

Altschul SF, Madden TL, Schaffer AA, Zhang J, Zhang Z, Miller W et al. Gapped BLAST and PSI-BLAST: a new generation of protein database search programs. Nucleic Acids Res. 1997; 25: 3389-3402.

Balagurunathan R, Subramanian A. Antagonistic Streptomycetes from marine sediments. Adv Biosci. 2001; 20: 71-76.

Barsby T, Kelly MT, Gagne SM, Andersen RJ: Bugorol A. produced in culture by a marine Bacillus sp. reveals a novel template for cationic peptide antibiotics. Org Lett. 2001; 3: 437-440.

Benson DA, Boguski MS, Lipman DJ, Ostell J, Oullette BFF, Rapp BA, Wheeler DL. GenBank. Nucleic Acids Res. 1999; 27: 12-17.

Brock TD, Madigan MT, Martiko JM, Parker J. Biology of Microorganisms. 7th edn. Englewood Cliffs. Prentice. Hall, International Inc, 1994.

Freshney RI, Hart E, Russell JM. Isolation and purification of cell cultures from human tumours. In Reid E, Cook, G M. W, Moore D J.(eds.), Cancer cell organelles; methodological surveys (B): Biochem Chicester, UK: Horwood 1982; 2: 97-110.

Gupte M, Kulkarni P, Ganguli BN. Antifungal antibiotics. Appl Microbiol Biotechnol. 2002; 58: 4657.

Hardt I, Jensen PR, Fenical W. Neomarinone, and new cytotoxic marinone derivatives, produced by a marine filamentous bacterium (Actinomycetales). Tetrahedron Lett. 2000; 41: 2073-2076.

Hollstein U. Actinomycin. Chemistry and mechanism of action. Chem Rev. 1974; 74 (6): 625-652.

Huangkai Z, Shenghan G, Wei-Hua C. EvolView, An online tool for visualizing, annotating and managing phylogenetic trees. Nucleic Acids Res. 2012; 40: 569572.

Jemimah NS, Subathra DC, Vaishnavi B, Mohanasrinivasan V. Screening for antimicrobial and antioxidant property of Streptomyces sp VITJS3 isolated from Bay of Bengal, Puducherry coast of India. J Pure Appl Microbiol. 2014; 8(1): 1125-1132.

Khalaf NA, Shakya AK, Al-Othman A, El-Agbar Z, Farah H. Antioxidant activity of some common plants. Turk J Biol. 2008; 32: 51-55.

Ko HR, Chun HK, Jung MC, Kho YH: Valistatin (3amino-2-hydroxy-4-phenylbutanoyl-valyl-valine), a new aminopeptidase $\mathrm{M}$ inhibitor, produced by Streptomyces sp.SL20209. J Microbiol Biotechnol. 2010; 5: 36-40.

Laidi RF, Elshafei A, Sanker M, Cheick B, Hocine H. Screening, isolation and characterization of a novel antimicrobial producing actinomycetes, strain RAF10. Biotechnol. 2007; 6: 489-496.
Manivasagan $\mathrm{P}$, Gnanam S, Sivakumar K, Thangaradjou T, Vijayalakshmi S, Balasubramanian T. Antimicrobial and cytotoxic activities of an actinobacteria (Streptomyces sp. PM-32) isolated from an offshore sediments of the Bay of Bengal in tamilnadu. Advances Biological Res. 2009; 3: 231 236.

Mellouli L, Mehdi RB, Sioud S, Salem M, Bejar S. Isolation, purification and partial characterization of antibacterial activities produced by a newly isolated Streptomyces sp. US24 strain. Res Microbiol. 2003; 154: 345-352.

Morakchi H, Ayari A, Taok M, Kirane D, Cochet N. Characterization of Streptomyces strain SLO-105 isolated from Lake Oubeira sediments in North-East of Algeria. Afr J Biotech. 2009; 8: 6332-6336.

Mosmann T. Rapid colorimetric assay for cellular growth and survival: application to proliferation and cytotoxicity assays. J Immunol Methods. 1983; 65: 55-63.

Nathan A, Magarvey Jessica M, Keller, Bernan V, Dworkin M, Sherman DH. Isolation and characterization of novel marine derived actinomycete taxa rich in bioactive metabolites. Appl Environ Microbiol. 2004; 70: 7520-7529.

Newman DJ, Gragg GM, Snader KM. Natural products as source of new drugs over the period 1981-2002. $J$ Nat Prod. 2003; 66: 1022-1037.

Oskay M. Antifungal and antibacterial compounds from Streptomyces strains. Afr J Biotech. 2009; 8: 3007-3017.

Pandey B, Ghimire P, Agrawal VP. Studies on the antimicrobial activity of actinomycetes isolated from Khumbu region of Nepal. PhD dissertation. Tribhuvan University, Kathmandu. Nepal: 2004.

Pina-Vaz C, Gonçalves-Rodrigues A, Pinto E, Costade-Oliveira S, Tavares C, Salgueiro L, et al. Antifungal activity of Thymus oils and their major compounds. J Eur Acad Dermatol Venereol. 2004; 18(1): 73-78.

Ponmurugan P, Nithya B. Plasmid DNA of antibiotic producing strains of Streptomyces sannanensis isolated from different states in Southern India. Biotechnol. 2008; 7: 487-492.

Rainey FA, Ward-Rainey NL, Kroppenstedt RM, Tackebrandt E. The genus Norcardiopsis represents a phylogenetically coherent taxon and a distinct actinomycete lineage: proposal of Nocaridiopsaceae fam. nov. Int J Syst Bacteriol. 1996; 46:1088-1092.

Ravikumar YS, Mahadevan KM, Kumaraswamy MN, Vaidya VP, Manjunatha H, Kumar V, et al. Antioxidant, Cytotoxic and Genotoxic evaluation of alcoholic extract of Polyalthia cerasoides (roxb) Bedd. Environ Toxicol Pharmacol. 2008; 26: 142146. 
Remya M, Vijayakumar R. Isolation and characterization of marine antagonistic actinomycetes from west coast of India. Med Biol. 2007; 5: 13-19.

Sajid I, Yao CB, Shaaban KA, Hasnain S, Laatsch H. Identification, isolation and optimization of antifungal metabolites from the Streptomyces malachitofuscus ctf9. World J Microbiol Biotechnol. 2009; 25: 601-610.

Sathish KS, Kokati VB. In vitro antimicrobial activity of marine actinobacteria against multidrug resistance Staphylococcus aureus. Asian Pac J Trop Biomed. 2012; 2(10): 787-792.
Taylor MW, Radax R, Steger D, Wagner M. Spongeassociated microorganisms: evolution, ecology, and biotechnological potential. Microbiol Mol Biol Rev. 2007; 1: 295-347.

Usha R, Ananthaselvi C, Venil-Paliniswamy $\mathrm{M}$. Antimicrobial and antiangiogenesis activity of Streptomyces KUAP106 from mangrove soil. European J Biol Sci. 2010; 2(4): 77-83.

Received: June 10, 2014 Accepted: August 03, 2014 